\author{
Michał Gacek ${ }^{1}$, \\ Pedagogical University of Kraków \\ Władysława Pilecka, Agnieszka Fusińska-Korpik² \\ Jagiellonian University
}

\title{
Psychometric properties of Self-Perception Profile for Children in a Polish sample 3
}

\begin{abstract}
:
The Self-Perception Profile for Children (SPPC) is a measure which allows one to assess children's self-concept. Our article presents this instrument's psychometric properties within a Polish sample. In our study we tested 432 elementary school students and 14 form teachers. As validity indicators we used the Teacher's Rating Scale of Child's Actual Behavior (TRS) and the average school grade for the previous semester. The Polish version of SPPC yielded good psychometric properties. The instrument's factorial structure paralleled the structure of the original version. Reliability was high both in terms of internal consistency and test-retest results. Scale validity was confirmed in the correlational analysis. Boys scored higher than girls in the Physical Appearance and Global Self-Worth subscales but lower in the Behavioral Conduct subscale. Younger children scored higher than older children in the Scholastic Competence, Physical Appearance, and Global Self-Worth subscales. Judgments on children's physical appearance were the best predictor of their global self-worth.
\end{abstract}

\section{Keywords:}

Self-Perception Profile, self-concept, self-esteem, cross-cultural validation, children

\section{Streszczenie:}

Skala Postrzegania Siebie dla Dzieci (Self-Perception Profile for Children) jest narzędziem służącym do badania obrazu siebie. Celem artykułu było przedstawienie własności psychometrycznych skali uzyskanych w grupie polskich dzieci. W badaniu wzięło udział 432 uczniów szkół podstawowych i 14 wychowawców klas. Trafność narzędzia określano poprzez odniesienie wyników uzyskanych w Skali Postrzegania Siebie dla Dzieci do wyników w Skali Oceny Zachowania Dziecka przez Nauczyciela oraz do średniej ocen uczniów z ostatniego semestru. Analizy statystyczne wskazały na

1 Michał Gacek, Chair of Psychology, Pedagogical University of Kraków, ul.Podchorążych 2; 30-084 Kraków; m.j.gacek@wp.pl.

2 Władysława Pilecka, Agnieszka Fusińska-Korpik, Institute of Psychology, Jagiellonian University, al. Mickiewicza 3; 31-120 Kraków.

3 The research presented in the article was supported by a grant of the Ministry of Science and Higher Education no. 0486/B/H03/2010/39. 
dobre własności psychometryczne narzędzia. Struktura czynnikowa skali okazała się podobna do tej, jaką zakładano w oryginalnej wersji. Rzetelność narzędzia, określana za pomocą wskaźników spójności wewnętrznej i korelacji z wynikiem badania retestowego, była wysoka. Chłopcy uzyskali wyższe wyniki niż dziewczęta w podskalach Wyglądu i Globalnego Poczucia Własnej Wartości, lecz niższe w podskali Kontroli Zachowania. Młodsze dzieci uzyskały wyższe wyniki niż starsze dzieci w podskalach Kompetencji Szkolnych, Wyglądu i Globalnego Poczucia Własnej Wartości. Ocena własnego wyglądu stanowiła najsilniejszy predyktor globalnego poczucia własnej wartości.

\section{Słowa kluczowe:}

Skala Postrzegania Siebie dla Dzieci, obraz siebie, samoocena, adaptacja międzykulturowa, dzieci

\section{Introduction}

The Self-Perception Profile for Children (SPPC) was originally developed by Susan Harter (1985) in the United States almost three decades ago and since then has become one of the most popular and widely recognized instruments to assess children's selfconcept. Cross-cultural scale validations have been prepared in Canada (a French version by Gavin \& Herry, 1996) and in European countries such as the Netherlands (van Dongen-Melman, Koot, and Verhulst, 1993; Murris, Meester, and Fijen, 2002), Belgium (van der Bergh, Marcoen, 1999), Greece (Makris-Botsaris, Robinson, 1991), Germany (Asendorpf, van Acken, 1993), France (Boivin, Vitaro, and Gagnon, 1992), Finland (Miller, 2000), Spain (Pereda, Forns, 2004), Northern Ireland (Granleese, Joseph, 1993), and Scotland (Hoare, Elton, Greer, and Kerley, 1993). The scale has also been used in studies conducted in culturally distant countries like the United Arab Emirates (Eapen, Naqvi, and Al Dhaheri, 2000), and China (Wang, Meredith, and Tsai, 1996). Despite its popularity SPPC has not been validated so far in Poland.

Self-concept is a frequently studied phenomenon in the social sciences (Leary, Tangney, 2005). Although there is no single prevailing definition of this term, generally it refers to an organized set of descriptive and evaluative judgments that a person attributes to themself. Descriptive judgments take into consideration different characteristics which constitute a person's self-knowledge, whereas evaluative judgments are related to appraisal of such characteristics in the context of personal and social standards. The term "self-concept" is often used interchangeably with the terms "self-esteem" or "self-worth" since a person's judgments tend to include both descriptive and evaluative qualities at the same time (e.g. Harter, Whitesell, and Junkin, 1998; Swann, ChangSchneider, and McClarty, 2007).

The main assumption made by the author of SPPC is that self-concept is a multidimensional construct undergoing significant structural changes in the course of development 
(Harter, 1986; Harter 1990; Harter 2005). The notion regarding self-concept as a multidimensional phenomenon is common in contemporary psychology (Marsh, Seeshing, 1998; Marsh, Trautwein, Ludtke, Koller, and Baumert, 2006; Lister, Roberts, 2011). In this approach different self-domains are usually viewed as separate but correlated. Researchers who develop their own instruments a priori assume a self-concept structure which is later confirmed via factor analysis (Marsh, Holmes, 1990; Huang, 2010). Selfdomains assessed by such instruments differ, depending on the theoretical basis and the aim of the research. For example, if a researcher is particularly interested in how children perceive themselves in specific academic situations one may want to test selfconcept for different school subjects, whereas for other researchers it may seem more appropriate to test only the perception of general academic competence (Shavelson, Bolus, 1982). It has been demonstrated (Marsh, Craven, 2006; Vallerand, Pelletier, and Gagne, 1991) that a multidimensional approach to self-concept allows for a more accurate measurement than the unidimensional approach proposed in earlier studies (e.g. Coopersmith, 1967; Niebrzydowski, 1976).

According to Harter (2005), developmental changes in self-concept are related to the level of a child's cognitive maturity, and social experiences. Regarding cognitive abilities, the author points out the significance of the processes of differentiation and integration in constructing knowledge about one's self. In the process of differentiation children create various self-descriptions which are independently evaluated. Such selfdescriptions are then integrated within higher-order generalizations about one's characteristics, for example, if a child perceives itself as good at writing, good at reading, and good at counting, it should later perceive itself as good at schoolwork or, in an even more abstract description, as smart or intelligent. The important social experiences that influence self-concept are related to the way a child is perceived by significant persons in its environment such as parents, teachers, or classmates. The amount of approval that a child receives is usually positively correlated with a child's self-evaluations. The way a child is perceived by others and by itself is mediated by social standards which may differ in some aspects for certain sexes or social groups, for example, it has been observed that girls from middle childhood evaluate their physical appearance more critically than boys. This may be explained by the different standards set for girls and boys within society (Harter, 1985; Harter, 2000).

Normative-developmental changes in self-concept occur in certain age periods (Harter, 2005). In ontogenesis the earliest judgments regarding self are observed in two to- four year-olds. Such children usually describe concrete and observable features of self which are not integrated into higher-order categories. Self-evaluations in this period tend to be unrealistically positive since children have trouble in distinguishing their 
desired and actual level of competence. First higher-order generalizations in the selfconcept are observed when children are on the verge of early and middle childhood. It has been shown that children aged four to seven evaluate themselves independently in two general categories. The first category-relates to their cognitive and physical competence level, and the second to their perceived social acceptance by persons in their environment (Harter, 1986; Harter, 1990). In middle and late childhood there emerges the ability to use abstract self-descriptive categories which integrate knowledge about different abilities, traits, and behaviors into a set of higher-order generalizations. Children's self-evaluations usually decrease with age and are much more positive and unrealistic in comparison to the self-appraisals given by adolescents (Oleszkowicz, Senejko, 2011).

SPPC assesses self-descriptions made by children aged 8 and older. The instrument consists of five domain-specific subscales and a global self-worth subscale (Harter, 1985). Domain-specific evaluations allow one to measure a child's self-perception in areas of 1) scholastic competence, 2) social acceptance, 3) athletic competence, 4) physical appearance, and 5) behavioral conduct. The Scholastic Competence subscale taps the child's own perceived cognitive abilities in a school context. The items refer to performance in schoolwork and the perception of oneself as smart. Social Acceptance taps the degree to which a child perceives itself as popular and liked by peers. Athletic Competence assesses the way a child peceives its own competence in sports and outdoor games. The Physical Appearance subscale taps the degree to which a child is happy with its own looks and physical characteristics such as height, weight, hair, and face. The Behavioral Conduct subscale allows one to assess the degree to which children like the way they behave, and whether they feel that they act the way they are supposed to and avoid getting into trouble. Finally, the Global Self-Worth subscale refers to the general acceptance of oneself as a person. The items in this subscale tap the extent to which a child likes itself, and whether the child is happy with its own life. It is important to notice that global self-worth in SPPC is not treated as a sum of different self-evaluations but is assessed by a separate set of statements. Such an approach comes from William James' formulation that self-esteem depends on success or failure in domains deemed important by the person. Thus, not all domain-specific evaluations are equally important predictors of a child's global self-worth. The other theoretical inspiration for Harter's instrument comes from the works of Charles Cooley, who has seen self as a social construct. From this perspective, judgments about self are influenced by the way a child is perceived by significant others, namely, parents or teachers. James's and Cooley's propositions found strong empirical confirmation in researches conducted with SPPC (Harter, 1986; Harter, 1990).

The importance of studying children's self-concept has been underlined by many authors who connect this construct to different psychological and behavioral variables. 
Among other things, low global self-worth has been correlated with depression (Abela, Fishman, Cohen, and Young, 2012; Harter, 1993), with high levels of aggression and externalizing problems (Brent Donellan, Trzesniewski, Robins, Moffitt, and Caspi 2005; Diamantopolou, Rydell, and Henrickson, 2008), child body dissatisfaction (Taylor, Wilson, Slater, and Mohr, 2012), sexual abuse (Bolger, Patterson, and Kupersmidt, 1998), and difficulties in school transition (West, Sweeting, and Young, 2008). High global selfworth has been positively correlated with general life satisfaction in children (Huebner, 1991), and academic performance (Baumeister, Campbell, Krueger, and Vohs, 2003). The relation of other domain-specific evaluations to other variables was also researched. In recent studies it was shown that perceived physical appearance moderated depressive symptoms in children (Nguyen, Scott, 2011), and perceived behavioral conduct was related to externalizing problems in child psychiatric patients (De Pauw, Mervielde, De Clercq, De Fruyt, Tremmery, and Deboutte., 2009). Also, in educational psychology, domain specific evaluations were stronger predictors of school achievement than global self-worth (Bong, Cho, Ahn, and Kim, 2012; Marsh, Martin, 2011).

SPPC was originally standarised by Harter (1985) on four samples of over 1,500 children from third grade (8-9 year-olds) till eighth grade (13-14 year-olds) who attended schools in Colorado, USA. SPPC cross-cultural studies conducted so far regarding psychometric properties have in most cases clearly supported the instrument's original factorial structure, indicating that the scale accurately taps the domains distinguished by children brought up in western culture (e.g. van der Bergh, Marcoen, 1999; Boivin et al., 1992; Granlese, Joseph, 1993; Makris-Botsaris, Robinson, 1991; Miller, 2000; Murris, Meester, and Fijen, 2002; Pereda, Forns, 2004). The developmental period of tested children in cross-cultural studies usually ranged from middle childhood to early adolescence depending on the research design and educational system specifics, for example, in Belgium authors tested children 8-12 years-old (van der Bergh, Marcoen, 1999), in Spain 9-12 yearsold (Pereda, Forns, 2004), and in the Dutch sample the first study included children 8-12 years-old (van Dongen-Melman, Koot, and Verhulst, 1993;), and a later study 8-14 yearsold (Murris, Meester, and Fijen, 2002). SPPC's validity was assessed cross-culturally by the teacher ratings (van der Bergh, Marcoen, 1999; Boivin et al., 1992), peer ratings (Boivin et al., 1992), perceived social support scores, and the discrepancy between competence and importance scores in the different domains (Miller, 2000).

A common finding in SPPC research was sex, and age differences in self-evaluations across the domains. In the American study boys scored higher than girls in the subscales of athletic competence, physical appearance, and global self-worth, while girls scored higher only on the behavioral conduct subscale (Harter, 1985). A similar tendency has been observed in most cross-cultural research, although sometimes boys scored 
higher than girls in all subscales except for behavioral conduct, for example, in studies conducted in Belgium (van der Bergh, Marcoen, 1999) or Scotland (Hoare et al., 1993); and sometimes sex differences were less striking, for example, in Spain boys' results were significantly higher only in the domain of athletic competence, and lower in the domain of behavioral conduct (Pereda, Forns, 2004). When it comes to age differences SPPC results usually confirm the cross-cultural tendency that younger children evaluate themselves higher than older children (van der Bergh, Marcoen, 1999; Harter, 1985; Hoare et al. 1993).

The objective in our current study was to investigate SPPC's psychometric properties in a group of Polish children. We decided first to examine the instrument using exploratory factor analysis. In the next step we tested the internal consistency of the subscales, intercorrelations, and test-retest reliability. We also studied the sample for sex, and age differences. To test the age differences we compared the results obtained by younger children in the second and third grades of elementary school with the results of older children in fourth to sixth grade. We assumed that comparing children in the middle childhood period with children in late childhood and early adolescence would allow us to demonstrate the decrease in self-evaluations typically observed in the course of development (Oleszkowicz, Senejko, 2011). We tested scale by using the Teacher's Rating Scale of Child's Actual Behavior (TRS), and by correlating SPPC results with the average school-grade for the previous semester. In ourfinal step, we checked which subscales would allow one to predict children's global self-worth.

\section{Method}

\section{Participants}

The sample consisted of 432 elementary school students recruited from state schools in Cracow. The participants'age ranged from 8 to 13 with a mean of 10.62 ( $\mathrm{SD}=1.45)$. There were 206 boys (mean age $=10.65, \mathrm{SD}=1.38$ ) and 226 girls (mean age $=10.59$, $\mathrm{SD}=1.51$ ). We also assessed 14 form teachers of the tested pupils, who completed the Teacher Rating Scale of Child's Actual Behavior for the total number of 215 students (mean age $=11.36, \mathrm{SD}=.96$ ) including 112 boys (mean age=11.25, $\mathrm{SD}=.98$ ) and 103 girls (mean age $=11.48$ and $\mathrm{SD}=.92$ ).

\section{Measurement}

\section{Self-Perception Profile for Children}

SPPC (Harter, 1985) enables one to test a child's self-perception in five domain-specific dimensions: 1) scholastic competence, 2) social acceptance, 3) athletic competence, 
4) physical appearance, and 5) behavioral conduct, and the sixth dimension of global self-worth. All 36 items are formulated as paired opposite statements. The child is asked to decide which statement describes themself better and whether this statement is only sort of true or really true for him or her. The answers are scored on a 1 to 4 scale: where 1 represents low perceived competence or adequacy and 4 reflects high perceived competence or adequacy. The final score for each dimension is the arithmetic mean of the scores in the six items.

The SPPC version we used was translated into Polish independently by two translators. Both translations were compared and discussed by psychologists experienced in developmental research. The more suitable translation was back-translated into English by another translator. After comparing the back-translation to the original SPPC a final Polish version was established.

\section{Teacher Rating Scale of Child's Actual Behavior}

The TRS was originally published in the same manual as SPPC (Harter, 1985). The structure of both questionnaires is parallel. Teachers are asked to rate children based on their actual behavior and the situation at school in five domain-specific dimensions. A global self-worth subscale is not included because of the strictly subjective nature of these kinds of judgments. The questionnaire contains 15 items scored on a 1 to 4 scale. The final score for each subscale is calculated as a mean of the scores in three items. This scale was translated similarly to the SPPC translation.

\section{Procedure}

Our study was approved by school authorities and by the parents of the tested children. Students filled in SPPC during form periods in their teacher's presence. Those who conducted the study first briefly presented themselves and the aim of the research. Then they gave instructions on how to complete the questionnaire. Form teachers filled in the TRS for their students at school in their free time. Also, when given consent, we obtained the average grades of the tested children for the previous semester. A retest study was conducted after a month in a group comprising 60 children.

\section{Statistical analysis}

Statistical analysis was conducted using SPSS 20. In order to confirm the factor structure of SPPC we performed exploratory factor analysis with varimax rotation on 30 items representing domain-specific subscales. Items composing the Global Self-Worth subscale were not included due to the fact that global self-esteem may depend on different 
domain-specific evaluations important to the child. As a next step in the analysis we tested scale reliability by assessing the $\alpha$-Cronbach's coefficients and the test-retest correlations. After this we examined the intercorrelations between the SPPC subscales, and ran the t-test to explore sex differences between the means. We also used the t-test to test the age differences between younger and older children. To assess the instrument's validity we correlated the results with the teacher's ratings measured by TRS, and with the children's average grade in the previous semester. We also performed regression analysis to determine the influence of domain-specific factors on global self-worth.

\section{Results}

\section{Factor analysis}

The scree plot generated for the 30 domain-specific SPPC items indicated the final break point in the data after the fifth factor (Figure 1). These factors explained 53\% of the variance (Factor 1: 24.6\%; Factor 2: 10.7\%; Factor 3: 7.2\%; Factor 4: 5.5\%; Factor 5: $4.9 \%$ ). The results obtained suggested a search for a five-factor solution within the analysis. Items were attributed to the factors based on their loadings exceeding a value of .40. We discovered that the factor structure reflected the assumed SPPC structure. As presented in Table 1, high loadings grouped the items to compose the dimensions of: physical appearance (F1), scholastic competence (F2), behavioral conduct (F3), athletic competence (F4), and social acceptance (F5). It is worth noticing that there were only three items, numbers 25,27 , and 33 , which had loadings exceeding the value of .30 in two separate factors. The first item "Some kids do very well at their classwork BUT other kids don't do very well at their classwork" loaded scholastic competence and behavioral conduct factors. This result may suggest that to some extent children in elementary school connect success at school with an ability to control their behavior and to act the way that is expected by adults. The second item was "In games and sports some kids usually watch instead of play BUT other kids usually play rather than watch". In this case the results indicate that children answered this item both in the context of their athletic competence and peer acceptance. Finally, the third item was "Some kids don't do well at new outdoor games BUT other kids are good at new games right away". This item was connected both to athletic and scholastic competence. 


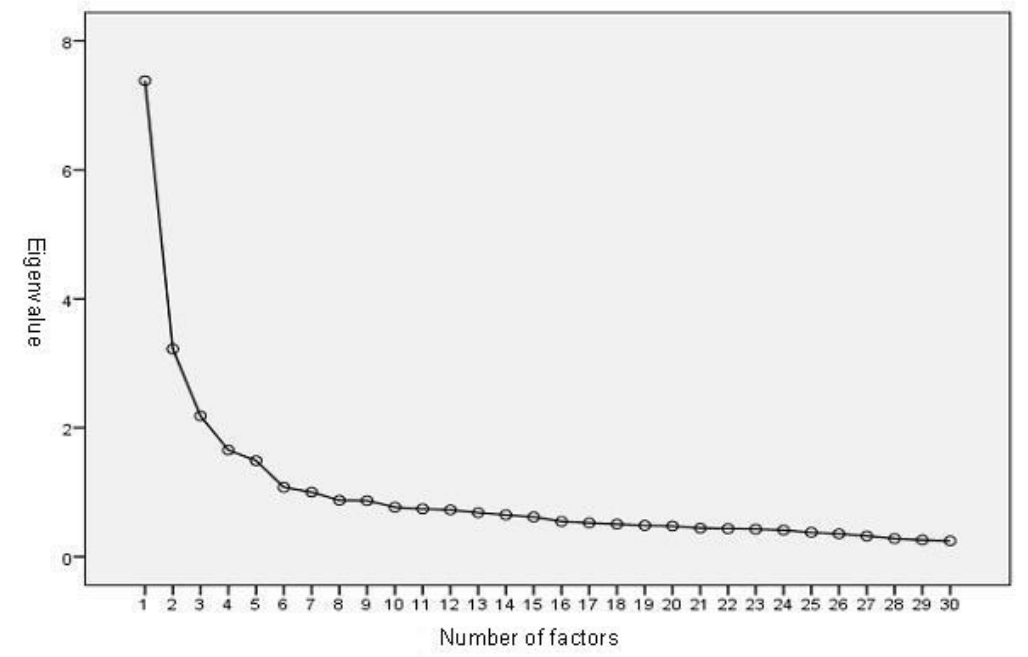

Figure 1. Scree plot of the factors representing items in the Polish version of SPPC.

Table 1. Factor loadings for the Polish version of SPPC.

\begin{tabular}{|c|c|c|c|c|c|}
\hline & F1 & F2 & F3 & F4 & F5 \\
\hline \multicolumn{6}{|l|}{ Scholastic competence (Cronbach's $\alpha=.78$ ) } \\
\hline $\begin{array}{l}\text { 1. Some kids feel that they are very good at their school work BUT } \\
\text { other kids worry whether they can do the school work assigned to them }\end{array}$ & .23 & $.70^{*}$ & .17 & .06 & .02 \\
\hline $\begin{array}{l}\text { 7. Some kids feel like they are just as smart as other kids their age BUT } \\
\text { other kids aren't so sure and wonder if they are as smart }\end{array}$ & .13 & $.65^{*}$ & .11 & .08 & -.06 \\
\hline $\begin{array}{l}\text { 13. Some kids are pretty slow in finishing their school work BUT other } \\
\text { kids can do their school work quickly }\end{array}$ & .06 & $.65^{*}$ & .07 & .17 & .13 \\
\hline $\begin{array}{l}\text { 19. Some kids often forget what they learn BUT other kids remember } \\
\text { things easily }\end{array}$ & .20 & $.59 *$ & .23 & .12 & .00 \\
\hline $\begin{array}{l}\text { 25. Some kids do very well at their classwork BUT other kids don't do } \\
\text { very well at their classwork }\end{array}$ & .10 & $.63^{*}$ & .32 & .06 & .13 \\
\hline $\begin{array}{l}\text { 31. Some kids have trouble figuring out the answers at school BUT } \\
\text { other kids almost always can figure out the answers }\end{array}$ & .09 & $.71 *$ & .16 & .01 & .22 \\
\hline \multicolumn{6}{|l|}{ Social acceptance (Cronbach's $\alpha=.70$ ) } \\
\hline $\begin{array}{l}\text { 2. Some kids find it hard to make friends BUT other kids find it pretty } \\
\text { easy to make friends }\end{array}$ & .06 & .00 & .03 & .13 & $.71 *$ \\
\hline $\begin{array}{l}\text { 8. Some kids have a lot of friends BUT other kids don't have very } \\
\text { many friends }\end{array}$ & .03 & -.00 & .03 & .24 & $.72 *$ \\
\hline $\begin{array}{l}\text { 14. Some kids would like to have a lot more friends BUT other kids } \\
\text { have as many friends as they want }\end{array}$ & .08 & .04 & -.01 & -.08 & $.54 *$ \\
\hline $\begin{array}{l}\text { 20. Some kids are always doing things with a lot of kids BUT other } \\
\text { kids usually do things by themselves }\end{array}$ & .06 & -.01 & .05 & .20 & $.58 *$ \\
\hline $\begin{array}{l}\text { 26. Some kids wish that more people their age liked them BUT other } \\
\text { kids feel that most people their age do like them }\end{array}$ & .13 & .24 & .17 & .21 & $.63 *$ \\
\hline $\begin{array}{l}\text { 32. Some kids are popular with othera their age BUT other kids are not } \\
\text { very popular }\end{array}$ & .06 & .19 & .13 & .20 & $.64 *$ \\
\hline
\end{tabular}




\begin{tabular}{|c|c|c|c|c|c|}
\hline $\begin{array}{l}\text { 3. Some kids do very well at all kinds of sports BUT other kids feel } \\
\text { that they are not very good when it comes to sports }\end{array}$ & .13 & .09 & -.06 & $.78^{*}$ & .11 \\
\hline $\begin{array}{l}\text { 9. Some kids wish they could be a lot better at sports BUT other kids } \\
\text { feel they are good enough at sports }\end{array}$ & .12 & .01 & .16 & $.59 *$ & .21 \\
\hline $\begin{array}{l}\text { 15. Some kids think they could do well at just about any new sports } \\
\text { activity they haven't tried before BUT other kids are afraid they might } \\
\text { not do well at sports they haven't tried }\end{array}$ & .14 & .06 & .09 & $.74 *$ & .14 \\
\hline $\begin{array}{l}\text { 21. Some kids feel that they are better than others their age at sports } \\
\text { BUT other kids don't feel they can play as well }\end{array}$ & .05 & .02 & .00 & $.76^{*}$ & .07 \\
\hline $\begin{array}{l}\text { 27. In games and sports some kids usually watch instead of play BUT } \\
\text { other kids usually play rather than watch }\end{array}$ & .13 & .20 & -.01 & $.50 *$ & .39 \\
\hline $\begin{array}{l}\text { 33. Some kids don't do well at new outdoor games BUT other kids are } \\
\text { good at new games right away }\end{array}$ & .08 & .31 & .00 & $.61 *$ & .19 \\
\hline \multicolumn{6}{|l|}{ Physical appearance (Cronbach's $\alpha=.84$ ) } \\
\hline $\begin{array}{l}\text { 4. Some kids are happy with the way they look BUT other kids are not } \\
\text { happy with the way they look }\end{array}$ & $.69^{*}$ & .11 & .16 & .19 & .08 \\
\hline $\begin{array}{l}\text { 10. Some kids are happy with their height and weight BUT other kids } \\
\text { wish their height or weight were different }\end{array}$ & $.63 *$ & .05 & .01 & .10 & .08 \\
\hline $\begin{array}{l}\text { 16. Some kids wish their body was different BUT other kids like their } \\
\text { body the way it is }\end{array}$ & $.74 *$ & .14 & .02 & .05 & .10 \\
\hline $\begin{array}{l}\text { 22. Some kids wish their physical appearance (how they look) was } \\
\text { different BUT other kids like their physical appearance the way it is }\end{array}$ & $.83 *$ & .11 & .09 & .06 & .10 \\
\hline $\begin{array}{l}\text { 28. Some kids wish something about their face or hair looked different } \\
\text { BUT other kids like their face and hair the way it is }\end{array}$ & $.70^{*}$ & .24 & .19 & .02 & .06 \\
\hline $\begin{array}{l}\text { 34. Some kids think that they are good looking BUT other kids think } \\
\text { that they are not very good looking }\end{array}$ & $.67 *$ & .12 & .24 & .20 & .04 \\
\hline \multicolumn{6}{|l|}{ Behavioral conduct (Cronbach's $\alpha=.78$ ) } \\
\hline $\begin{array}{l}\text { 5. Some kids often do not like the way they behave BUT other kids } \\
\text { usually like the way they behave }\end{array}$ & .01 & .02 & $.49 *$ & .15 & .10 \\
\hline $\begin{array}{l}\text { 11. Some kids usually do the right thing BUT other kids often don't do } \\
\text { the right thing }\end{array}$ & .18 & .18 & $.76^{*}$ & .02 & .03 \\
\hline \begin{tabular}{|l|} 
17. Some kids usually act the way they know they are supposed to \\
BUT other kids often don't act the way they are supposed to
\end{tabular} & .16 & .06 & $.77 *$ & .03 & .00 \\
\hline $\begin{array}{l}\text { 23. Some kids usually get in trouble because of things they do BUT } \\
\text { other kids usually don't do things that get them in trouble }\end{array}$ & .01 & .29 & $.57 *$ & -.02 & .08 \\
\hline $\begin{array}{l}\text { 29. Some kids do things they know they shouldn't do BUT other kids } \\
\text { hardly ever do things they know they shouldn't do }\end{array}$ & .17 & .23 & $.56 *$ & -.02 & .01 \\
\hline $\begin{array}{l}\text { 35. Some kids behave themselves very well BUT other kids often find } \\
\text { it hard to behave themselves }\end{array}$ & .10 & .22 & $.78 *$ & -.02 & .07 \\
\hline
\end{tabular}

$\mathrm{n}=432 *$ salient $(>.40)$.

\section{Reliability}

The internal consistency of all SPPC subscales was good. Cronbach's $\alpha$ coefficients for domain-specific evaluations ranged between .70 for Social Acceptance and .84 for Physical Appearance. Cronbach's $\alpha$ for Global Self-Worth was .76. The test-retest study was 
conducted after one month in a group of 60 children ( 31 boys and 29 girls). The obtained correlations were high for all the domain-specific subscales. Pearson's r coefficients ranged between .64 and .82 (Table 5). The correlation with the retest score for Global Self-Worth was moderate $(\mathrm{r}=.50)$. These results suggest that self-perception in domainspecific areas is more stable in time than global self-esteem, which may still shift to a certain extent in a relatively short period of time.

\section{Intercorrelations}

All correlations between SPPC subscales were significant $(\mathrm{p}<.001)$, but Pearson's $\mathrm{r}$ coefficients were mostly low or moderate (Table 2). The only case in which r exceeded .50 was the correlation between the Global Self-Worth and Physical Appearance. The only r value below .20 was observed between Behavioral Conduct and Athletic Competence. The pattern of correlations confirms the assumption that SPPC subscales measure different aspects of one theoretical construct.

Table 2. Intercorrelations for the subscales in the Polish version of SPPC.

\begin{tabular}{|l|c|c|c|c|c|}
\hline & $\begin{array}{l}\text { Social } \\
\text { Acceptance }\end{array}$ & $\begin{array}{l}\text { Athletic } \\
\text { Competence }\end{array}$ & $\begin{array}{l}\text { Physical } \\
\text { Appearance }\end{array}$ & $\begin{array}{l}\text { Behavioral } \\
\text { Conduct }\end{array}$ & $\begin{array}{l}\text { Global } \\
\text { Self-worth }\end{array}$ \\
\hline $\begin{array}{l}\text { Scholastic Compe- } \\
\text { tence }\end{array}$ & $.27^{*}$ & $.31^{*}$ & $.41^{*}$ & $.48^{*}$ & $.50^{*}$ \\
\hline Social Acceptance & & $.45^{*}$ & $.26^{*}$ & $.20^{*}$ & $.42^{*}$ \\
\hline $\begin{array}{l}\text { Athletic Compe- } \\
\text { tence }\end{array}$ & & & $.33^{*}$ & $.16^{*}$ & $.36^{*}$ \\
\hline $\begin{array}{l}\text { Physical Appear- } \\
\text { ance }\end{array}$ & & & & $.35^{*}$ & $.63^{*}$ \\
\hline Behavioral Conduct & & & & & $.46^{*}$ \\
\hline
\end{tabular}

$\mathrm{n}=432 * \mathrm{p}<.001$.

\section{Sex differences}

In Table 3 we included the means and standard deviations for the six subscales. Due to the fact that self-perception develops within the context of cultural expectations which differ for boys and girls, we tested the sample for gender differences. We discovered that boys evaluated themselves significantly higher in two subscales: Physical Appearance $(\mathrm{t}=2.46, \mathrm{p}=.01)$ and Global Self-Worth $(\mathrm{t}=2.17, \mathrm{p}=.03)$, whereas girls obtained significantly higher scores in the Behavioral Conduct subscale $(\mathrm{t}=-3.55, \mathrm{p}<.01)$. These results show that boys perceive themselves as being more content with their looks and generally happier with the way they are than girls. On the other hand, girls see themselves as better behaved than boys. We did not observe any difference between means in Athletic Competence, something which was systematically obtained in American research (Harter, 1985) and research conducted in other European countries (e.g. van der Bergh, Marcoen, 1999; Hoare et al., 1993). 
Table 3. Means, standard deviations, and sex differences for the SPPC subscales in the Polish version.

\begin{tabular}{|c|c|c|c|c|c|c|c|c|c|c|}
\hline & \multicolumn{2}{|c|}{} & \multicolumn{2}{c|}{$\begin{array}{c}\text { Boys } \\
\mathrm{n}=206\end{array}$} & \multicolumn{2}{c|}{$\begin{array}{c}\text { Girls } \\
\mathrm{n}=226\end{array}$} & & \multicolumn{2}{c|}{ Levene test } \\
\hline & $\mathrm{M}$ & $\mathrm{SD}$ & $\mathrm{M}$ & $\mathrm{SD}$ & $\mathrm{M}$ & $\mathrm{SD}$ & $\mathrm{t}$ & $\mathrm{p}$ & $\mathrm{F}$ & $\mathrm{p}$ \\
\hline Scholastic Competence & 2.90 & .65 & 2.92 & .63 & 2.88 & .67 & .63 & .52 & .37 & .54 \\
\hline Social Acceptance & 3.25 & .71 & 3.28 & .75 & 3.22 & .67 & .80 & .42 & .00 & .93 \\
\hline Athletic Competence & 2.98 & .71 & 3.04 & .69 & 2.92 & .73 & 1.74 & .08 & .32 & .57 \\
\hline Physical Appearance* & 3.05 & .74 & 3.14 & .68 & 2.97 & .78 & 2.46 & .01 & 7.15 & $<.01$ \\
\hline Behavioral Conduct & 3.03 & .62 & 2.92 & .65 & 3.13 & .57 & -3.55 & $<.01$ & 3.84 & .05 \\
\hline Global Self-worth* & 3.32 & .57 & 3.38 & .50 & 3.27 & .62 & 2.17 & .03 & 10.55 & $<.01$ \\
\hline
\end{tabular}

* - the difference was tested with the assumption of an inequality of variance as indicated by the Levene test.

\section{Age differences}

To study age differences we divided the sample into two subgroups. In the first subgroup we included children in the second and third grade, whereas the other subgroup comprised pupils from fourth to sixth grade. Obtained means, as presented in Table 4, were higher for all subscales in the group of younger children. Significant differences were observed for three subscales: Scholastic Competence $(t=-2.00, p=.04)$, Physical Appearance $(\mathrm{t}=-5.19, \mathrm{p}<.01)$, and Global Self-Worth $(\mathrm{t}=-3.64, \mathrm{p}<.01)$. These results show that children tend to become more critical in their self-evaluations as they grow older. The decrease in self-concept affects mostly cognitive abilities perceived in the school context, and one's physical features. General acceptance of oneself as a person also declines.

Table 4. Age differences in self-evaluations for the SPPC subscales in the Polish version.

\begin{tabular}{|c|c|c|c|c|c|c|c|c|}
\hline & \multicolumn{2}{|c|}{$\begin{array}{c}\text { Middle childhood } \\
(8-9-\text {-year-olds }) \\
\mathrm{n}=127\end{array}$} & $\begin{array}{c}\text { Late childhood/ } \\
\text { early adolescence } \\
(10-13 \text {-year-olds }) \\
\mathrm{n}=305\end{array}$ & \multicolumn{2}{|c|}{ Levene test } \\
\hline & $\mathrm{M}$ & $\mathrm{SD}$ & $\mathrm{M}$ & $\mathrm{SD}$ & $\mathrm{t}$ & $\mathrm{p}$ & $\mathrm{F}$ & $\mathrm{p}$ \\
\hline Scholastic Competence & 2.99 & .65 & 2.86 & .65 & -2.00 & .04 & .01 & .92 \\
\hline Social Acceptance & 3.31 & .83 & 3.23 & .66 & -1.06 & .28 & 1.28 & .25 \\
\hline Athletic Competence & 3.05 & .67 & 2.94 & .73 & -1.40 & .16 & 1.66 & .19 \\
\hline Physical Appearance & 3.33 & .69 & 2.97 & .73 & -5.19 & $<.01$ & .58 & .44 \\
\hline Behavioral Conduct & 3.11 & .62 & 3.00 & .61 & -1.70 & .09 & .21 & .64 \\
\hline Global Self-worth & 3.48 & .51 & 3.26 & .58 & -3.64 & $<.01$ & 3.73 & .05 \\
\hline
\end{tabular}

\section{Validity}

As indicators of SPPC validity we used TRS, and the average school grade in the previous semester (Table 5). SPPC correlations with teacher's ratings were moderate in four out of the five domain-specific subscales. The highest correlation was observed in scholastic competence $(\mathrm{r}=.47, \mathrm{p}<.001)$. This result was expected since form teachers perceive 
children firstly according to their school performance. We did not observe a significant correlation when we evaluated physical appearance. This may be due to the fact that children's subjective evaluations in this aspect are connected rather to the judgments of parents or other children and not teachers who usually do not make comments on a child's physical appearance.

Children's average school grades in the previous semester correlated strongly with the results in the Scholastic Competence subscale $(\mathrm{r}=.58, \mathrm{p}<.001)$. The second highest correlation was obtained for Behavioral Conduct $(r=.37, \mathrm{p}<.001)$. These results suggest that the children's grades in elementary school are connected both to their perceived academic skills and to their perceived behavior. The connection to behavior may suggest that children who get good grades often feel that they act in the right way, the way that is expected by adults.

Table 5. Correlations of SPPC subscales with retest results, teacher's ratings, and school grades.

\begin{tabular}{|l|c|c|c|}
\hline & $\begin{array}{c}\text { Test-retest } \\
\mathrm{n}=60\end{array}$ & $\begin{array}{c}\text { Teacher rating's } \\
\mathrm{n}=215\end{array}$ & $\begin{array}{c}\text { Average school grade in the } \\
\text { previous semester } \\
\mathrm{n}=178\end{array}$ \\
\hline Scholastic Competence & $.70^{* *}$ & $.47^{* *}$ & $.58^{* *}$ \\
\hline Social Acceptance & $.82^{* *}$ & $.32^{* *}$ & $.17^{*}$ \\
\hline Athletic Competence & $.67 * *$ & $.45^{* *}$ & .09 \\
\hline Physical Appearance & $.80^{* *}$ & .13 & $.25^{*}$ \\
\hline Behavioral Conduct & $.64 * *$ & $.31 * *$ & $.37^{* *}$ \\
\hline Global Self-worth & $.50^{* *}$ & ---- & $.21^{*}$ \\
\hline
\end{tabular}
$* \mathrm{p}<.05 * * \mathrm{p}<.001$.

\section{Predictors of global self-worth}

We used regression analysis to state which domain-specific judgments influence children's global self-worth. The model presented in Table 6 had an F $(5,426)$ of 103.35 $(\mathrm{p}<.001)$. $\mathrm{R}$ value was .74 and the adjusted $\mathrm{R}^{2}=.54$. Results in the physical appearance subscale were the strongest predictor of global self-worth (Beta $=.43, \mathrm{t}=11.66, \mathrm{p}<.001$ ). Similar results were observed in other studies (e.g. Boivin et al, 1992; Harter, 2000). The influence of other subscales was significant but not as crucial with the exception of Athletic Competence which proved to be non-significant in the constructed model. These results show that the perception of one's physical appearance is the most important domain-specific evaluation influencing global self-esteem. When children are happy with the way they look it strongly predicts the way they evaluate themselves as a person and if they are happy with their lives. 
Table 6. Regression data for the regression of global self-worth on to the domain-specific self-evaluations.

\begin{tabular}{|l|c|c|c|c|c|}
\hline & $\mathrm{B}$ & Standard error of B & Beta & $\mathrm{t}$ & $\mathrm{p}$ \\
\hline Constant & .74 & .12 & & 6.02 & $<.001$ \\
\hline Scholastic Competence & .14 & .03 & .16 & 4.02 & $<.001$ \\
\hline Social Acceptance & .17 & .03 & .21 & 5.73 & $<.001$ \\
\hline Athletic Competence & .02 & .03 & .03 & .90 & .36 \\
\hline Physical Appearance & .33 & .02 & .43 & 11.66 & $<.001$ \\
\hline Behavioral Conduct & .16 & .03 & .18 & 4.76 & $<.001$ \\
\hline
\end{tabular}

\section{Discussion}

In our study we tested the psychometric properties of SPPC in a sample of Polish children. The results of exploratory factor analysis indicated that the tested children clearly distinguished between the five domain-specific subscales included in the instrument. Thus, we confirmed that the factorial structure of the Polish version is similar to the one in the original instrument (Harter, 1985). The reliability of the Polish version of SPPC was high both in terms of internal consistency, with the $\alpha$-Cronbach's coefficients ranging from .70 to .84 , and in the correlated test-retest results $(r>.60)$ for all domain-specific subscales. The lowest correlation in the retest study conducted after a month was observed in the Global Self-Worth subscale which suggests that the estimation of global self-esteem may be less stable in time than the evaluation in domain-specific areas.

Scores in all the SPPC subscales were significantly intercorrelated. The highest correlation was observed between Physical Appearance and Global Self-Worth, which suggests that the perceived physical features are closely connected to the general evaluation of oneself as a person. A similar result was obtained by Harter (1985) in the original study, and by other authors (Boivin et al., 1992; van Dongen-Melman et al., 1993). The high correlation between physical appearance and global self-worth may be explained by their similar contents - both refer rather to the sense of satisfaction than to the degree of competence as is the case with the other subscales (see van der Bergh, Marcoen, 1999).

The sex differences in our study showed that boy's global self-worth was higher that the girl's. Also, boys had higher self-concepts in physical appearance, but lower in behavioral conduct. A similar tendency for boys to rate themselves higher than girls was observed in most studies in Europe and America (e.g. Harter, 1985; van Dongen-Melman et al., 1993; Hoare et al., 1993). Differences in the perception of physical appearance between boys and girls may be explained by the higher standards set for girls in this aspect in society. Such standards may lead to a situation whereby girls see themselves in a more critical way and tend to be more unhappy with the way they look. Girls' higher 
results in the domain of behavioral conduct may be explained by the fact that girls are usually perceived by significant others as calmer and better behaved than boys.

The results obtained by younger and older students confirm that children tend to become more critical in their self-evaluations over the course of development. A similar tendency was found in other studies (e.g. Harter, 1985; Hoare et al., 1993; van der Bergh, Marcoen, 1999). We observed that eight to- nine year-olds evaluated themselves higher than 10-13 year-olds in the domains of physical appearance, scholastic competence, and global self-worth. Especially the difference in evaluating physical features seems to show that younger children are much more content with their bodies and the way they look. Only at the turn of late childhood and early adolescence when children confront their self-concept with social standards in order to achieve gender identity does the growing dissatisfaction with physicality occur (Oleszkowicz, Senejko, 2011).

Instrument validity was tested by correlating the SPPC results with the TRS results, and school grades. Teacher's ratings were related to children's evaluations in all domains except physical appearance. This result shows that teacher and student judgments are fairly concordant. Differences in evaluating physical appearance may be due to the fact that usually teachers do not comment on children's looks. This may suggest that children's self-perceptions are connected rather to the judgments of parents and peers. Similar findings regarding a lack of correspondence between student and teacher physical appearance ratings were reported also in other studies (Boivin et al., 1992; van der Bergh, Marcoen, 1999). School grades correlated strongly with the children's perception of scholastic competence and behavioral conduct. This result confirms the tendency observed in educational research that a child's academic self-concept level is related to school achievement (Baumeister et al., 2003). The connection to the behavioral conduct domain suggests that children who get good grades in elementary school feel that their behavior is proper and that they act in the way that is expected by adults.

Also, in our study we showed that the perceived physical appearance has the most influence on global self-worth (Beta $=.43, \mathrm{p}<.001$ ). Such a finding may be explained by the emphasis placed on appearance within contemporary culture. Physical features are usually presented in the media as significant in a broad range of situations which suggests that they are more important than other self-aspects. Similar results regarding the importance of physical appearance were observed in other studies (Boivin et al., 1992; van der Bergh, Marcoen, 1999). The second best global self-worth predictor was the result in the Social Acceptance subscale $(\mathrm{Beta}=.21, \mathrm{p}<.001)$ which confirms that children feel it is important to be popular and liked by peers. Also, global self-worth was influenced significantly by the results in the Behavioral Conduct (Beta $=.18, \mathrm{p}<.001$ ), and the Scholastic Competence (Beta=.16, p<.001) subscales. Except for Physical Appearance, the Beta-weights for all other subscales were similar. 
In conclusion, our study confirmed that the Polish version of SPPC is a reliable and valid measure to assess children's self-concept. We can recommend this instrument for use both in individual diagnosis as equally in academic research.

\section{References:}

Abela, J. R. Z., Fishman, M. B., Cohen, J. R., \& Young, J. F. (2012). Personality predispositions to depression in children of affectively-ill parents: The buffering role of selfesteem. Journal of Clinical Child and Adolescent Psychology, 41 (4), 391-401.

Asendorpf, J. B., van Aken, M. A. G. (1993). Deutsche Versionen der Selbstkonzeptskalen von Harter. Zeitschrift f. Entwicklungpsychologie u Pädagogische Psychologie, 25 (1), 64-86.

Baumeister, R. F., Campbell, J. D., Krueger, J. I., Vohs, K. D. (2003). Does high selfesteem cause better performance, interpersonal success, happiness, or healthier lifestyles? Psychological Science in the Public Interest, 4(1), 1-44.

Boivin, M., Vitaro, \& F., Gagnon, C. (1992). A reassessment of the Self-Perception Profile for Children: Factor structure, reliability, and convergent validity of a French version among second through sixth grade children. International Journal of Behavioral Development, 15 (2), 275-290.

Bolger, K. E., Patterson, J., \& Kupersmidt, J. (1998). Peer relationships and self-esteem among children who have been maltreated. Child Development, 69(4), 1171-1197.

Bong, M., Cho, C., Ahn, H. S., \& Kim, H. J. (2012). Comparison of self-beliefs for predicting student motivation and achievement. Journal of Educational Research, 105 (5), 336-352.

Brent Donnellan, M., Trzesniewski, K. H., Robins, R. W., Moff.itt, T. E., \& Caspi, A. (2005). Low self-esteem is related to aggression, antisocial behavior, and delinquency. Psychological Science, 16(4), 328-335.

Coopersmith, S. (1967). The antecedents of self-esteem. San Francisco, Freeman press.

De Pauw, S. S., Mervielde, I., De Clercq, B. J., De Fruyt, F., Tremmery, S., \& Deboutte, D. (2009). Personality symptoms and self-esteem as correlates of psychopathology in child psychiatric patients: Evaluating multiple informant data. Child Psychiatry and Human Development, 40(4), 499-515.

Diamantopoluou, S., Rydell, \& A. M., Henricsson, L. (2008). Can both low and high selfesteem be related to aggression in children? Social Development, 17 (3), 682-698. 
Eapen, V., Naqvi, A., \& Al-Dhaheri, A. (2000). Cross-cultural validation of Harter's Self-Perception Profile for Children in the United Arab Emirates. Annals of Saudi Medicine, 20 (1), 8-11.

Gavin, D., A., W., Herry, Y. (1996). The French Self-Perception Profile for Children: Score validity and reliability. Educational and Psychological Measurement, 4 (56), 678-700.

Granleese, J., Joseph, S. (1994). Further psychometric validation of the Self-Perception Profile for Children. Personality and Individual Differences, 16 (4), 649-651.

Harter, S. (1985). Manual for the Self-Perception Profile for Children, Denver: University Press.

Harter, S. (1986). Processes underlying the construction, maintenance, and enhancement of the self-concept in children. In J. Suls \& A. G. Greenwald (Eds.), Psychological perspectives on the self(Vol. 3, pp. 137-181), Hillsdale, N. J.: Erlbaum.

Harter, S. (1990). Issues in assessment of the self-concept of children and adolescents. In A. La Greca (Ed.), Childhood assessment: Through the eyes of a child (pp. 292-325). Boston, MA: Allyn and Bacon.

Harter, S. (1993). Causes and consequences of low self-esteem in children and adolescents. In R.F. Baumeister (Ed.), Self-Esteem: The Puzzle of low self-regard. New York: Plenum.

Harter, S., Whitesell, N. R., Junkin, L. J. (1998). Similarities and differences in domainspecific and global self-evaluations of learning-disabled, behaviorally disordered and normally achieving adolescents. American Educational Research Journal, 4 (35), 653-680.

Harter, S. (2000). Is Self-Esteem Only Skin-Deep? The Inextricable Link between Physical Appearance and Self-Esteem. Reclaiming Children and Youth, 3 (9), 133-138.

Harter, S. (2005). The development of self-representations during childhood and adolescence. In M. R. Leary, J. P. Tangney (Eds.), Handbook of self and identity (pp. 610-643). New York: Guilford Press.

Hoare, F., Elton, R., Greer, A., \& Kerley, S. (1993). The modification and standardisation of the Harter Self-Esteem Questionnaire with Scottish school children. European Child \& Adolescent Psychiatry, 2 (1), 19-33.

Huang, C. (2010). Mean-level change in self-esteem from childhood through adulthood: Meta-analysis of longitudinal studies. Review of General Psychology, 14(3), 251-260. 
Huebner, E. S. (1991). Correlates of life satisfaction in children. School Psychology Quarterly, 6 (2), 103-111.

Leary, M. R., Tangney J. P. (2005). The self as an organizing construct in the behavioral and social sciences. In M. R. Leary, J. P. Tangney (Eds.), Handbook of self and identity (pp. 3-15). New York: Guilford Press.

Lister, K., Roberts, J. (2011). The self-concepts and perceived competencies of gifted and non-gifted students: A meta-analysis. Journal of Research in Special Educational Needs, 11(2), 130-140.

Makris-Botsaris, E., Robinson, W., P. (1991). Harter's Self-Perception Profile for Children: A cross cultural validation in Greece. Evaluation \& Reasearch in Education, 3(5), 135-143.

Marsh, H. W., Holmes, I. W. (1990). Multidimensional self-concepts: Construct validation of responses by children. American Educational Research Journal, 27(1), 89-117.

Marsh, H. W., Seeshing, Y. A. (1998). Top-down, bottom-up, and horizontal models: The direction of causality in multidimensional, hierarchical self-concept models. Journal of Personality and Social Psychology, 75(2), 509-527.

Marsh, H. W., Craven, R. G. (2006). Reciprocal effects of self-concept and performance from a multidimensional perspective: Beyond seductive pleasure and unidimensional perspectives. Perspectives on Psychological Science, 1(2), 133-163.

Marsh, H. W., Trautwein, U., Lüdtke, O., Köller, O., \& Baumert, J. (2006). Integration of multidimensional self-concept and core personality constructs: Construct validation and relations to well-being and achievement. Journal of Personality, 74 (2), 403-456.

Marsh, H. W., Martin, A. J. (2011). Academic self-concept and academic achievement: Relations and casual ordering. British Journal of Educational Psychology, 81(1), 59-77.

Miller, H-M. (2000). Cross-cultural validity of a model of self-worth: Application to Finish children. Social Behavior and Personality: an international journal, 28(2), 105-118.

Murris, P., Meesters, C., Fijen, P. (2003). The Self-Perception Profile for Children: Further evidence for its factor structure, reliability, and validity. Personality and Individual Differences, 35, 1791-1802. 
Nguen, H. T., Scott, A. N. (2013). Self-Concept and depression among children who experienced the death of a family member. Death Studies, 37, 197-211.

Niebrzydowski, L. (1976). O poznawaniu i ocenie samego siebie: na przykładzie młodzieży dorastającej. Warszawa: Nasza Księgarnia.

Oleszkowicz A., Senejko A. (2011). Dorastanie. In: J. Trempała (ed.), Psychologia rozwoju człowieka. (pp.259-286). Warszawa: PWN.

Pereda, N., Forns, M. (2004). Psychometric properties of the Spanish version of the SelfPerception Profile for Children. Perceptual and Motor Skills, 98 (2), 685-699.

Shavelson, R. J., Bolus, R. (1981). Self concept: The interplay of theory and methods. Journal of Educational Psychology, 74(1), 3-17.

Swann W. B., Chang-Schneider C., McClarty K. L. (2007). Do people's self-view matter? Self-concept and self-esteem in everyday life. American Psychologist, 62 (2), 84-94.

Taylor, A., Wilson, C., Slater, A., \& Mohr, P. (2012). Self-esteem and body dissatisfaction in young children: Associations with weight and perceived parenting style. Clinical Psychologist, 16, 25-35.

Van den Bergh, B. R. H., Marcoen, A. (1999). Harter's Self-Perception Profile for Children: Factor structure, reliability, and convergent validity in a Dutch-speaking Belgian sample of fourth, fifth and sixth graders. Psychologica Belgica, 39 (1), 29-47.

Vallerand, R. J., Pelletier, L. G., \& Gagné, F. (1991). On the multidimensional versus unidimensional [erspectives of self-esteem: A test using the group-comparison approach. Social Behavior and Personality, 19 (2), 121-132.

Van Dongen-Melman, J., E., W., M., Koot, H., M., \& Verhulst, F., C. (1993). Cross-cultural validation of Harter's Self-Perception Profile for Children in a Dutch Sample. Educational and Psychological Measurement, 53 (3), 739-753.

Wang, A., Meredith, W. H., \& Tsai, R. (1996). Comparison in three Chinese cultures of scores on the self-perception profile for children. Perceptual and Motor Skills, 82 (3c), 1087-1095.

West, P., Sweeting, H., Young, R. (2010). Transition matters: Pupils' experiences of the primary-secondary school transition in the West of Scotland and consequences for well-being and attainment. Research Papers in Education, 25 (1), 21-50. 
